\title{
Present trophic level of Lake Alserio (Northern Italy) and prospect for its recovery
}

\author{
Michela ROGORA, Letizia GARIBALDI ${ }^{1}$, Giuseppe MORABITO, Silvia ARISCI and Rosario MOSELLO* \\ C.N.R. Istituto per lo Studio degli Ecosistemi, L.go Tonolli 50, 28922 Verbania Pallanza, Italy \\ ${ }^{1)}$ Dip. Scienze Ambiente e Territorio, Università degli Studi di Milano Bicocca, Piazza dell'Ateneo Nuovo 1, 20126 Milano, Italy \\ *e-mail corresponding author: r.mosello@iii.to.cnr.it
}

\begin{abstract}
Lake Alserio is located in the subalpine area of Northern Italy, in the Brianza region near Lake Como. In November 1999 an EU funded project was started with the aim of devising and implementing interventions leading to the recovery of the lake and the surrounding area, which is characterised by a high degree of biodiversity as regards species and natural habitats. Since the seventies, Lake Alserio has been affected by eutrophication, which has resulted in high phosphorus $(P)$ concentrations (annual average in 1999: 80-100 $\left.\mu \mathrm{g} \mathrm{Pl}^{-1}\right)$. The EU project envisaged liming the lake with $\mathrm{Ca}(\mathrm{OH})_{2}$ to reduce $\mathrm{P}$ concentrations in the water. This paper presents and discusses the results of chemical analyses performed on the lake and its tributaries in the first year of the study (November 1999-November 2000). The efficiency of liming with $\mathrm{Ca}(\mathrm{OH})_{2}$ to reduce $\mathrm{P}$ concentrations in laboratory and enclosure experiments is also discussed. The present condition of Lake Alserio is between eutrophic and hypereutrophic. Anoxic conditions characterise the hypolimnic waters for a prolonged period (May - October) during summer stratification, with a consequent high $P$ release from the sediments (summer P concentrations in the deep water are close to $1 \mathrm{mg} P \mathrm{l}^{-1}$ ). Inflowing waters are characterised by high contents of ammonium and phosphorus, showing the importance of domestic sewage in the lake catchment; external load is still too high to permit the water to reach mesotrophic condition, the ultimate goal of recovery. Results of the liming experiments suggest that the treatment, if applied to Lake Alserio, could accelerate its recovery, although the specific procedures to be employed are still to be defined. However, before these or any other remedial operations can be undertaken, the external P load must be reduced by completing the diversion of sewage from the lake.
\end{abstract}

Key words: eutrophication, lake restoration, liming, phosphorus

\section{INTRODUCTION}

Lake Alserio (Fig. 1) is located in Brianza, the part of the Northern Italian subalpine area enclosed between the two arms of Lake Como. Five other lakes (Pusiano, Annone-Oggiono, Segrino and Montorfano) with similar morphometric features and origins are found in the same area. All have glacial origin and were formed in the Quaternary period from the moraine deposits of the great Valtellina Glacier. The main geographical and morphometric characteristics of Lake Alserio, the object of this study, are shown in table 1.

The Lake Alserio area, including the wetland around the lake, is characterised by a high degree of biodiversity as regards species and natural habitats, so that it has been recognised as a "Site of European interest".

About 12,900 people live in the lake catchment, which has an average population density of 755 inhab. $\mathrm{km}^{-2}$ (Chiaudani \& Premazzi 1992). As in the whole Brianza area, there was a boom in industrial activity during the sixties, with serious consequences for the water quality. Little information is available on the evolution of the trophic level of the lake. However, the available data (Bonomi et al. 1967; Gerletti \& Marchetti 1977; de Bernardi et al. 1985; Chiaudani \& Premazzi 1992; Negri et al. 1995, 1996, 1997) (Fig. 2), leave no doubts that Lake Alserio was already highly eutrophic at the beginning of the seventies. Since then, the $\mathrm{P}$ content of the lake water has decreased from about $180 \mu \mathrm{g} \mathrm{P}^{-1}$ (mean values on the whole water column measured at spring mixing) to $70-80 \mu \mathrm{g} \mathrm{P}^{-1}$ in recent years. This was due both to the reduction of phosphorus in detergents, from values above $6.5 \%$ in the seventies to values below 1\% in 1988 (Pagnotta \& Passino 1992; Provini et al. 1992), and to the construction of a pipe conveying urban waste water and runoff to a treatment plant in the nearby town of Merone, outside the lake watershed.

In spite of these measures, the present phosphorus concentration in the lake is still too high: values on the whole water column in autumn 1999, when this study started, were $80-100 \mu \mathrm{g} \mathrm{P}^{-1}$, with the highest value of about $900 \mu \mathrm{g} \mathrm{P}{ }^{-1}$ in the hypolimnion during thermal stratification, highlighting the importance of the internal phosphorus load (Rogora et al. 2001). Moreover, this deterioration process has involved the whole area, particularly the surrounding wetland, with a marked regression of the peat-bog area.

In November 1999 the EU funded a three-year project to devise and implement measures for the recovery of the environment in this area. The project aims are the recovery of lake water quality, particularly of its original mesotrophic conditions, as well as the conservation and re-naturalization of the vegetal biocenosis in the 

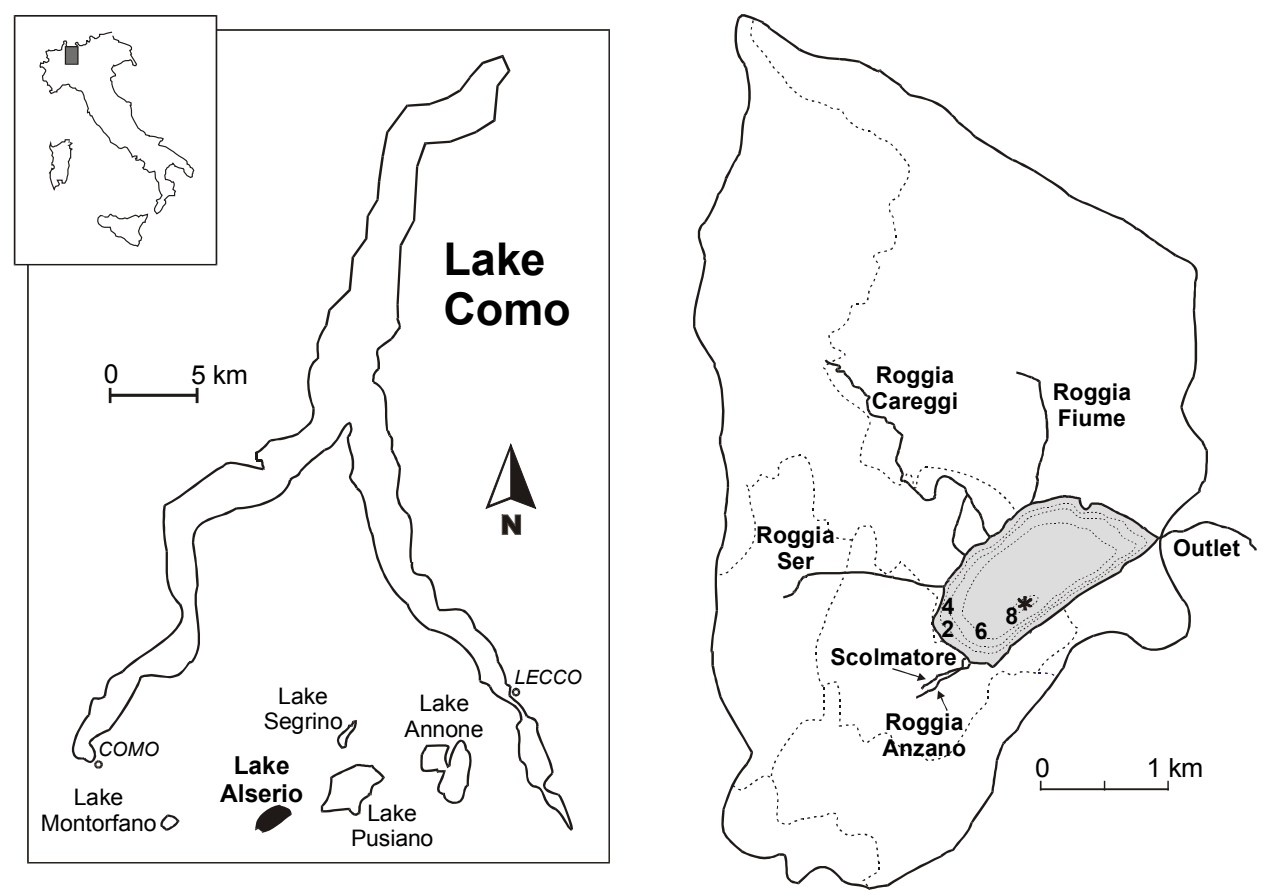

Fig. 1. Location of Lake Alserio in Northern Italy (left); Lake Alserio watershed with the main tributaries (right). *: lake water sampling point.

surrounding area. The project includes two interventions to reduce the huge amount of phosphorus in the lake water: liming with $\mathrm{Ca}(\mathrm{OH})_{2}$, following laboratory and enclosure experiments to test the efficiency of the process, and the withdrawal of hypolimnetic water during thermal stratification.

Tab. 1. Main geographical and morphometric characteristics of Lake Alserio and its watershed.

\begin{tabular}{lcc}
\hline Latitude N & & $45^{\circ} 47^{\prime}$ \\
Longitude E Greenwich & & $9^{\circ} 13^{\prime}$ \\
Mean lake altitude & $\mathrm{m} \mathrm{a.s.1.}$ & 260 \\
Lake area & $\mathrm{km}^{2}$ & 1.23 \\
Watershed area (lake included) & $\mathrm{km}^{2}$ & 18.3 \\
Watershed area/lake area & & 14.9 \\
Shore line & $\mathrm{km}$ & 5.02 \\
Max depth & $\mathrm{m}$ & 8.1 \\
Mean depth & $\mathrm{m}$ & 5.3 \\
Volume & $\mathrm{m}^{3} 10^{6}$ & 6.55 \\
Outflow discharge (1982-91) & $\mathrm{m}^{3} \mathrm{~s}^{-1}$ & 0.54 \\
Theoretical renewal time & years & 0.33 \\
\hline
\end{tabular}

This paper presents and discusses the results of chemical analyses performed on the lake and its tributaries in the first year of the study; it focused on quantifying the P load entering the lake from the watershed, in relation with the lake's current trophic state. The efficiency of liming with $\mathrm{Ca}(\mathrm{OH})_{2}$ in reducing $\mathrm{P}$ concentrations in laboratory and enclosure treatments is also discussed, as is the question of whether it is necessary or advisable to lime the whole lake.

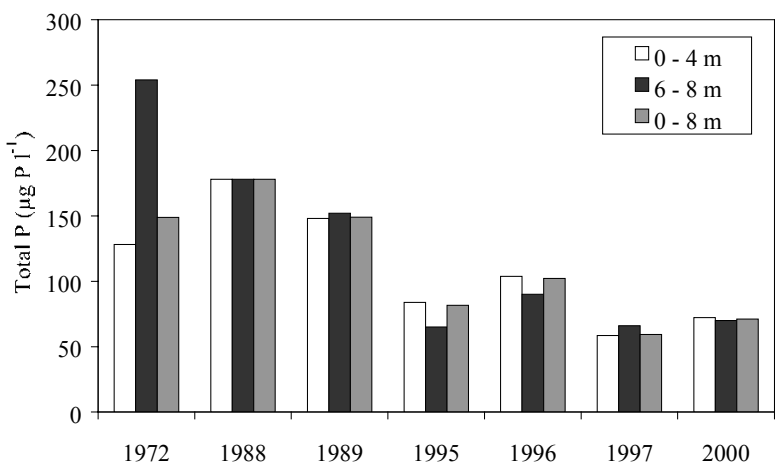

Fig. 2. The long-term trend of Lake Alserio trophic level: mean phosphorus concentrations measured at spring water mixing in the different water layers.

\section{METHODS}

\subsection{Study area}

The Lake Alserio watershed (Fig. 1) belongs to the basin of the River Lambro, a tributary of the River Po. The main tributaries of the lake are the Roggia Careggi, Roggia Ser, Roggia Parco Anzano, Roggia Fiume and some minor but not always unimportant watercourses, making up a complex hydrological pattern. The lithology of the watershed is characterised by sediment formations of the Trias and Giurese periods, without metamorphic or igneous rocks. Most of the watershed is covered by morainic deposits of the ancient Quaternary period while more recent material of alluvial origin is located around the lake. In the southern part of the area, 
Tab. 2. Analytical methods used in the analysis on Lake Alserio water. L.O.D.: limit of detection; R.S.D.: relative standard deviation.

\begin{tabular}{|c|c|c|c|c|c|c|}
\hline \multirow[t]{2}{*}{ Variables } & \multirow[t]{2}{*}{ Methods } & \multirow[t]{2}{*}{ Units } & \multirow[t]{2}{*}{ L.O.D. } & \multicolumn{2}{|c|}{ Repeatability } & \multirow[t]{2}{*}{ References } \\
\hline & & & & Mean & R.S.D. & \\
\hline $\mathrm{pH}$ & Potentiometry & & & & & Westcott 1978 \\
\hline Conductivity & Conductometry & $\begin{array}{l}\mu \mathrm{S} \mathrm{cm}^{-1} \\
\mu \mathrm{S} \mathrm{cm}^{-1}\end{array}$ & 0.5 & $\begin{array}{c}14.3 \\
186.1\end{array}$ & $\begin{array}{l}1.4 \\
0.6\end{array}$ & A.P.H.A., A.W.W.A., W.P.C.F. 1992 \\
\hline Alkalinity & Potentiometry & $\begin{array}{l}\mu \text { eq } 1^{-1} \\
\mu \text { eq } 1^{-1} \\
\mu e q 1^{-1}\end{array}$ & 1 & $\begin{array}{c}37 \\
539 \\
1924\end{array}$ & $\begin{array}{l}5.6 \\
0.7 \\
1.4\end{array}$ & Gran 1952 \\
\hline Nitrate & Ion chromatography (Dionex) & $\begin{array}{l}\mu \text { eq } 1^{-1} \\
\mu \text { eq } 1^{-1}\end{array}$ & 1 & $\begin{array}{l}14 \\
38\end{array}$ & $\begin{array}{c}3 \\
1.7\end{array}$ & A.P.H.A., A.W.W.A., W.P.C.F. 1992 \\
\hline Nitrite & Spectrophotometry & $\mu \mathrm{g} \mathrm{N} 1^{-1}$ & 1 & & & A.P.H.A., A.W.W.A., W.P.C.F. 1981 \\
\hline Ammonium & Spectrophotometry & $\begin{array}{l}\mu \mathrm{g} \mathrm{N}^{-1} \\
\mu \mathrm{g} \mathrm{N}-^{-1}\end{array}$ & 5 & $\begin{array}{c}46 \\
320\end{array}$ & $\begin{array}{l}8.2 \\
3.4\end{array}$ & Fresenius et al. 1988 \\
\hline Total nitrogen & Spectrophotometry & $\begin{array}{l}\mu \mathrm{g} \mathrm{N} 1^{-1} \\
\mu \mathrm{g} \mathrm{N} 1^{-1} \\
\mu \mathrm{g} \mathrm{N} 1^{-1}\end{array}$ & 200 & $\begin{array}{c}540 \\
1210 \\
4850\end{array}$ & $\begin{array}{l}5.6 \\
3.3 \\
0.8\end{array}$ & $\begin{array}{l}\text { Valderrama } 1981 \\
\text { A.P.H.A., A.W.W.A., W.P.C.F. } 1981\end{array}$ \\
\hline Reactive phosphorus & Spectrophotometry & $\begin{array}{l}\mu \mathrm{g} \mathrm{P} 1^{-1} \\
\mu \mathrm{g} \mathrm{P} 1^{-1} \\
\mu \mathrm{g} \mathrm{P} 1^{-1}\end{array}$ & 5 & $\begin{array}{c}8 \\
165 \\
355\end{array}$ & $\begin{array}{c}12.4 \\
0.8 \\
1.1\end{array}$ & Valderrama 1977 \\
\hline Total phosphorus & Spectrophotometry & $\begin{array}{l}\mu \mathrm{g} \mathrm{P} 1^{-1} \\
\mu \mathrm{g} \mathrm{P} 1^{-1} \\
\mu \mathrm{g} \mathrm{P} 1^{-1}\end{array}$ & 6 & $\begin{array}{c}14 \\
137 \\
303\end{array}$ & $\begin{array}{l}11.5 \\
3.9 \\
3.6\end{array}$ & Valderrama 1981 \\
\hline Reactive silica & Spectrophotometry & $\begin{array}{l}\mathrm{mg} \mathrm{l}^{-1} \\
\mathrm{mg} \mathrm{l}^{-1}\end{array}$ & 0.02 & $\begin{array}{l}0.42 \\
2.61\end{array}$ & $\begin{array}{l}7.1 \\
1.1\end{array}$ & Golterman et al. 1978 \\
\hline Sulphate & Ion chromatography (Dionex) & $\mu$ eq $1^{-1}$ & 2 & $\begin{array}{l}34 \\
58\end{array}$ & $\begin{array}{l}8.2 \\
4.3\end{array}$ & A.P.H.A., A.W.W.A., W.P.C.F. 1992 \\
\hline Chloride & Ion chromatography (Dionex) & $\begin{array}{l}\mu \text { eq } 1^{-1} \\
\mu \text { eq } 1^{-1}\end{array}$ & 0.5 & $\begin{array}{l}6 \\
9\end{array}$ & $\begin{array}{l}10 \\
6.3\end{array}$ & A.P.H.A., A.W.W.A., W.P.C.F. 1992 \\
\hline Calcium & Ion chromatography (Dionex) & $\begin{array}{l}\mu \text { eq } 1^{-1} \\
\mu \text { eq } 1^{-1}\end{array}$ & 0.5 & $\begin{array}{l}27 \\
74\end{array}$ & $\begin{array}{l}6.3 \\
3.6\end{array}$ & E.P.A. 1986 \\
\hline Magnesium & Ion chromatography (Dionex) & $\begin{array}{l}\mu \text { eq } 1^{-1} \\
\mu \text { eq } 1^{-1}\end{array}$ & 1 & $\begin{array}{c}9 \\
58\end{array}$ & $\begin{array}{l}5.7 \\
2.8\end{array}$ & E.P.A. 1986 \\
\hline Sodium & Ion chromatography (Dionex) & $\begin{array}{l}\mu \text { eq } 1^{-1} \\
\mu \text { eq } 1^{-1}\end{array}$ & 0.5 & $\begin{array}{c}5 \\
11\end{array}$ & $\begin{array}{l}10 \\
7.9\end{array}$ & E.P.A. 1986 \\
\hline Potassium & Ion chromatography (Dionex) & $\begin{array}{l}\mu \text { eq } 1^{-1} \\
\mu \text { eq } 1^{-1}\end{array}$ & 0.2 & $\begin{array}{l}3 \\
8\end{array}$ & $\begin{array}{c}13.2 \\
7.7\end{array}$ & E.P.A. 1986 \\
\hline
\end{tabular}

calcareous formations of the Tertiary period are also present (Gerletti \& Marchetti 1977).

The climate in the Brianza region is sub-continental temperate (Köppen \& Wegener 1940) with average annual temperature between $10{ }^{\circ} \mathrm{C}$ and $14.4{ }^{\circ} \mathrm{C}$. The pluviometric regime of the region is quite uniform during the year, with the highest rainfall in autumn and springsummer, a lower amount of precipitation in summer and the minimum in winter. Mean annual precipitation volume is between 1400 and $1600 \mathrm{~mm}$ (Gerletti \& Marchetti 1977).

The outflow discharge for the period 1955-69 was $0.59 \mathrm{~m}^{3} \mathrm{~s}^{-1}$ (Gerletti \& Marchetti 1977) and $0.54 \mathrm{~m}^{3} \mathrm{~s}^{-1}$ for the period 1982-91 (Pagotto, unpublished data). From this value a theoretical renewal time of the water of 0.33 years has been estimated.

\subsection{Sampling and analysis}

Lake Alserio was sampled monthly from the beginning of the project (November 1999). Field measurements included Secchi disk transparency, temperature and dissolved oxygen (multi-parameter probe, Microprocessor Oximeter WTW OXI 196). Water samples were taken at the deepest point of the lake, at 5 different

depths: 0, 2, 4, 6 and $7.5 \mathrm{~m}$ (bottom). The following analyses were performed on each sample: $\mathrm{pH}$, conductivity, alkalinity, reactive and total phosphorus, ammonium, nitrate, nitrite, total nitrogen, reactive silica, chloride and sulphate. $\mathrm{Ca}^{++}, \mathrm{Mg}^{++}, \mathrm{Na}^{+}, \mathrm{K}^{+}$were measured three times during the year, in March, June and November 2000, to evaluate the ionic composition of the lake water. The main tributaries of the lake and the outlet were sampled fortnightly and analysed for the same variables routinely measured in the lake water, except dissolved oxygen. Chemical methods are described in table 2 .

\subsection{Liming experiments}

Laboratory experiments and tests in enclosures were performed to evaluate the efficiency of liming in the coprecipitation of dissolved phosphorus. The laboratory experiments involved adding $\mathrm{Ca}(\mathrm{OH})_{2}$ and alternatively, $\mathrm{CaCO}_{3}$ to water samples of Lake Alserio, to evaluate the precipitation process under controlled conditions and to test the efficiency of the two different treatments. Variations in $\mathrm{pH}$ were closely noted in these experiments, particularly the peak values eventually reached during the addition. Alkalinity, main ions $\left(\mathrm{Ca}^{++}, \mathrm{Mg}^{++}\right.$, 
$\mathrm{Na}^{+}, \mathrm{K}^{+}$), nitrogen, phosphorus and reactive silica were also measured at fixed intervals. The calcium oxide used for the laboratory experiments, the same as was used in the lake experiments, is a commercial product used in building; its chemical composition is shown in table 3 .

Tab. 3. Chemical composition of calcium hydroxide used for the liming experiments.

\begin{tabular}{lcc}
\hline Title as $\mathrm{Ca}(\mathrm{OH})_{2}$ & \% weight & 92.8 \\
Water & \% weight & 0.6 \\
$\mathrm{CaO}$ & \% weight & 74.3 \\
$\mathrm{MgO}$ & \% weight & 0.2 \\
$\mathrm{CO}_{2}$ & \% weight & 3.0 \\
$\mathrm{SiO}_{2}$ & \% weight & 0.06 \\
$\mathrm{Fe}_{2} \mathrm{O}_{3}$ & \% weight & 0.013 \\
$\mathrm{Al}_{2} \mathrm{O}_{3}$ & \% weight & 0.06 \\
$\mathrm{SO}_{3}$ & \% weight & 0.01 \\
$\mathrm{As}$ & ppm & 0.08 \\
$\mathrm{Cr}$ & ppm & 0.65 \\
$\mathrm{Hg}$ & ppm & 0.09 \\
$\mathrm{~Pb}$ & ppm & 0.3 \\
$\mathrm{Mn}$ & ppm & 5.3 \\
\hline
\end{tabular}

Tab. 4. Characteristics of the two liming experiments in enclosures.

\begin{tabular}{lcc}
\hline & Liming 1 (August) & Liming 2 (December) \\
\hline Period & $07 / 08 / 00-11 / 09 / 00$ & $01 / 12 / 00-15 / 01 / 01$ \\
Amount of CaO added (g) & 2155 & 4025 \\
Enclosure height (m) & 6 & 7 \\
Diameter (m) & 3 & 3 \\
Lake water column & 5 & 6 \\
$\mathrm{~N}^{\circ}$ of samplings & 6 & 4 \\
Sampling depths (m) & $0-2-4$ & $0-3-5$ \\
\hline
\end{tabular}

Liming experiments in enclosures on Lake Alserio were performed twice: in August, during the period of thermal stratification, and in November-December, at the winter overturn. Two enclosures were used in both experiments, one to which $\mathrm{Ca}(\mathrm{OH})_{2}$ was added $(\mathrm{T})$ and the second used as a blank (C). The water column near the enclosures was also sampled. The conditions of the two experiments are summarized in table 4 . The enclosures were made of polyethylene (PET for the upper part and HDPE for the lower part), and a rigid steel framework (Fig. 3). They were open at the bottom and embedded in the sediment. In the first experiment, they were positioned at more than $150 \mathrm{~m}$ from the shore of the lake, where the depth is about $5 \mathrm{~m}$; in the autumn experiment they were located in the same part of the lake, but at a depth of about $6 \mathrm{~m}$. At each sampling, temperature, $\mathrm{pH}$, conductivity and dissolved oxygen were measured every $0.5 \mathrm{~m}$ using the multi-parameter probe on the water column, inside the two enclosures and also in the lake water close to them. Three samples were taken for each enclosure and for the lake, at 0,2 and $4 \mathrm{~m}$ depth $(0,3$ and $5 \mathrm{~m}$ in the second experiments). $\mathrm{pH}$, conductivity, alkalinity, main cations $\left(\mathrm{Ca}^{++}, \mathrm{Mg}^{++}\right.$,
$\left.\mathrm{Na}^{+}, \mathrm{K}^{+}\right)$and anions $\left(\mathrm{SO}_{4}{ }^{-}, \mathrm{NO}_{3}{ }^{-}\right.$and $\left.\mathrm{Cl}^{-}\right)$, reactive and total phosphorus, ammonium, total nitrogen and reactive silica were measured on each sample. Alkalinity measurements on the samples from enclosure $\mathrm{T}$ were performed after filtration $(0.45 \mu \mathrm{m})$, to prevent part of the suspended $\mathrm{CaCO}_{3}$ from reacting during the acidimetric tritration and leading to overestimation of the alkalinity values. Reactive and total phosphorus were always analysed both before and after filtration. For the analytical methods see table 2 .

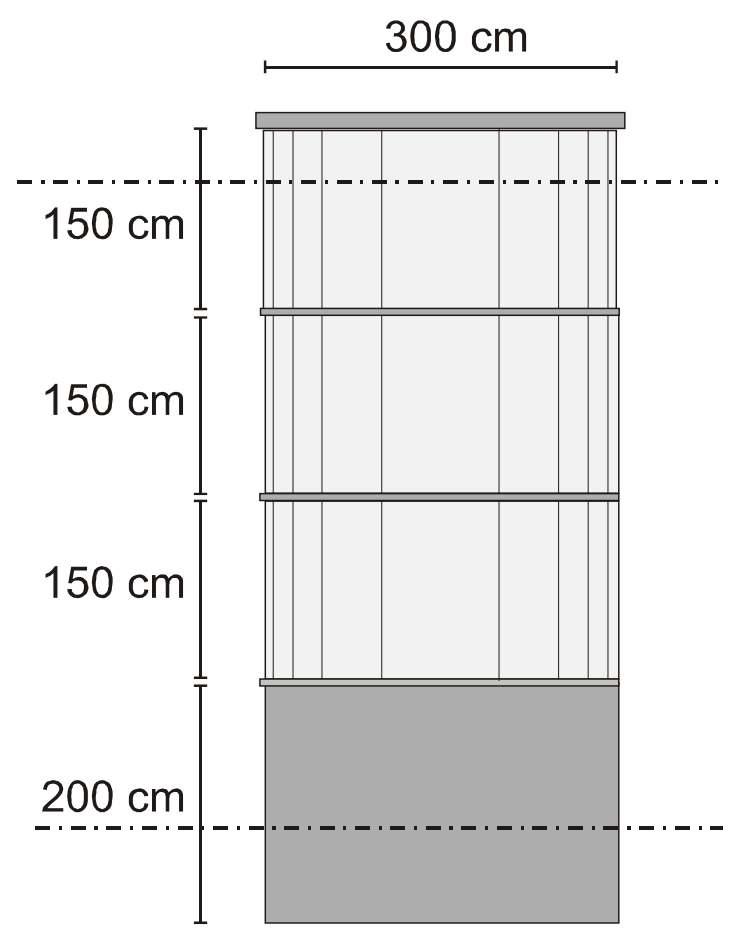

Fig. 3. Enclosure used for the liming experiments in Lake Alserio.

The liming treatment was carried out as follows: $\mathrm{Ca}(\mathrm{OH})_{2}$ was mixed with water in a 1001 tank on a boat. The solution was then pumped into the enclosure and distributed at different depths. We used a larger quantity of $\mathrm{Ca}(\mathrm{OH})_{2}$ in the second experiment (Tab. 4), as the in-lake phosphorus concentrations were higher than those of the summer period.

\subsection{Inorganic carbon and calcite equilibria}

Inorganic carbon speciation and calcite saturation were calculated using the stoichiometric approach as described e.g. by Stumm \& Morgan (1981) and A.P.H.A., A.W.W.A. \& W.E.F. (1995), from the measured variables: temperature, conductivity, alkalinity, $\mathrm{pH}$, calcium. Activity coefficients for mono- and bivalent ions and the equilibrium constants for inorganic carbon and calcite were calculated taking into account water temperature and ionic strength (IS, mole $1^{-1}$ ), following A.P.H.A., A.W.W.A. \& W.E.F. (1995). IS was 
obtained from conductivity, using a regression calculated from a subset of analyses of Lake Alserio water where major ion concentrations were measured.

The departure of calcium and carbonate ions from calcite solubility equilibrium was evaluated as the ratio $(\Omega)$ between the Ionic Activity Product (IAP), i.e. the product of the calculated activities of calcium and carbonate, and the calcite solubility product, Ks:

$$
\Omega=\mathrm{IAP} / \mathrm{Ks}=\left[\mathrm{Ca}^{++}\right] \times\left[\mathrm{CO}_{3}{ }^{=}\right] / \mathrm{Ks}
$$

The activities of calcium and carbonate were obtained from the activity factors (extended Debye-Hückel approximation, Stumm \& Morgan 1981) and from the concentrations of calcium (ion chromatography, Tab. 2) and carbonate.

$\Omega$ values higher than 1 indicate over-saturation of calcite, while under-saturation is indicated by $\Omega$ values lower than 1.

\section{RESULTS}

\subsection{Lake}

Lake Alserio was thermally stratified from March to October (Fig. 4), with a maximum difference between epilimnion and hypolimnion of $14{ }^{\circ} \mathrm{C}$ in June. Thermal stratification disappeared at the end of October, when the water underwent a partial mixing: in November the same temperature of $10{ }^{\circ} \mathrm{C}$ was measured over the whole water column.

The ionic content of the water was high (about 9.0 meq $\mathrm{l}^{-1}$, mean values at winter overturn), with conductivity values between 370 and $400 \mu \mathrm{S} \mathrm{cm}{ }^{-1}$ at $20{ }^{\circ} \mathrm{C}$ (Tab. 5). The dominant cation and anion are calcium and bicarbonate, which together represented about $80 \%$ of the total ionic content. In June calcium and alkalinity values in the water surface were lower than those in the deep water, as a consequence of biogenic precipitation of calcium carbonate.

Dissolved oxygen and $\mathrm{pH}$ varied similarly seasonally (Fig. 4) because they are mainly influenced by photosynthesis in the epilimnion and the decomposition in the hypolimnion. In July-August, when dissolved oxygen saturation in surface waters was $120-130 \%, \mathrm{pH}$ reached its maximum value of 8.5 , while during the winter overturn $\mathrm{pH}$ values were 7.5-7.6. The deepest waters were characterized by anoxic conditions from mid May to October: in November, at the overturn, dissolved oxygen saturation was $25 \%$. The consequent oversaturation of $\mathrm{CO}_{2}$ in the hypolimnion produced a gradual decrease of $\mathrm{pH}$ from 8.2 (March) to 7.0 (November).

Changes in alkalinity give a clear indication of the precipitation $\mathrm{CaCO}_{3}$, which started in April-May; in the epilimnion alkalinity values decreased steadily from 4.0 to $2.0 \mathrm{meq} 1^{-1}$ from April to August, slightly increasing in autumn as a result of inputs from atmospheric precipitation and runoff. In the hypolimnion, partial dissolution of sinking calcite and dissolution from sediments produced an increase of alkalinity, up to the highest values of 5.2-5.4 meq ${ }^{-1}$ measured in July-September (Fig. 4).

Low redox potential of the deep waters in summer is highlighted by the trend of nitrogen compounds (Fig. 4): ammonium concentrations, low at spring overturn, reached $8.0 \mathrm{mg} \mathrm{N} \mathrm{l}^{-1}$, while nitrates were totally depleted by reduction processes. Mean values of reactive and total phosphorus (RP, TP) at the overturn were 8090 and 100-120 $\mathrm{g} \mathrm{P}^{-1}$, respectively (Fig. 4). Phosphorus evidently begins to be utilised by phytoplankton in March, which is when concentrations in the epilimnion started to decrease; minimum values were measured in August-September (2 and $40 \mu \mathrm{g} \mathrm{P}^{-1}$ as RP and TP, respectively), while maximum concentrations (830 and $870 \mu \mathrm{g} \mathrm{P}^{-1}$ ) characterized the deepest waters at the end of August, due to the release of phosphorus from settling materials (calcite and organic matter) and from the sediments (Fig. 4).

\subsection{Rivers}

All the streams discharging into the lake present high ion concentrations, as indicated by conductivity values, which range from 420 to $609 \mu \mathrm{S} \mathrm{cm}-1$ at $20{ }^{\circ} \mathrm{C}$; mean alkalinity values are in the range 4.0-5.4 meq 1-1 (Tab. 6). In the case of Roggia Ser, there are two distinct periods: before and after June 2000, when sewage treatment was increased. Added waste water sent to the treatment plant resulted in a reduction of $\mathrm{P}$ and $\mathrm{N}$ concentrations in stream water, though TP values remained quite high (about $80 \mu \mathrm{g} \mathrm{P}^{-1}$ ) even after the diversion. On the whole, the river waters were characterized by high contents of ammonium and phosphorus, an indication of continuing release of domestic sewage in the lake catchment. Water from the pipe overflow (Scolmatore, Tab. 6) still had very high TP and ammonium concentrations. The pipe overflow was intended to prevent input of large volumes of clean water to the treatment plant, where it would decrease the efficiency of the treatment; and conversely this causes an extra input of $\mathrm{P}$ to the lake.

\subsection{Liming - laboratory experiments}

Experiments were carried out in the chemical laboratory of the Istituto per lo Studio degli Ecosistemi, aimed at evaluating the best operative conditions for the addition of $\mathrm{Ca}(\mathrm{OH})_{2}$ to the water of Lake Alserio to obtain the co-precipitation of phosphorus with calcium carbonate. The purpose was to see how effective this method was in precipitating phosphorus, compared to the direct addition of $\mathrm{CaCO}_{3}$ to the lake water, and to evaluate the different effects on $\mathrm{pH}$ of the two methods.

A first set of experiments was performed on small volumes of water from Lake Alserio $(100-500 \mathrm{ml})$. Small amounts $(1 \mathrm{ml})$ of a solution of $\mathrm{Ca}(\mathrm{OH})_{2}$ at a concentration of $1 \mathrm{~g} \mathrm{l}^{-1}$ were added to the water and the $\mathrm{pH}$ measured during the experiment. 

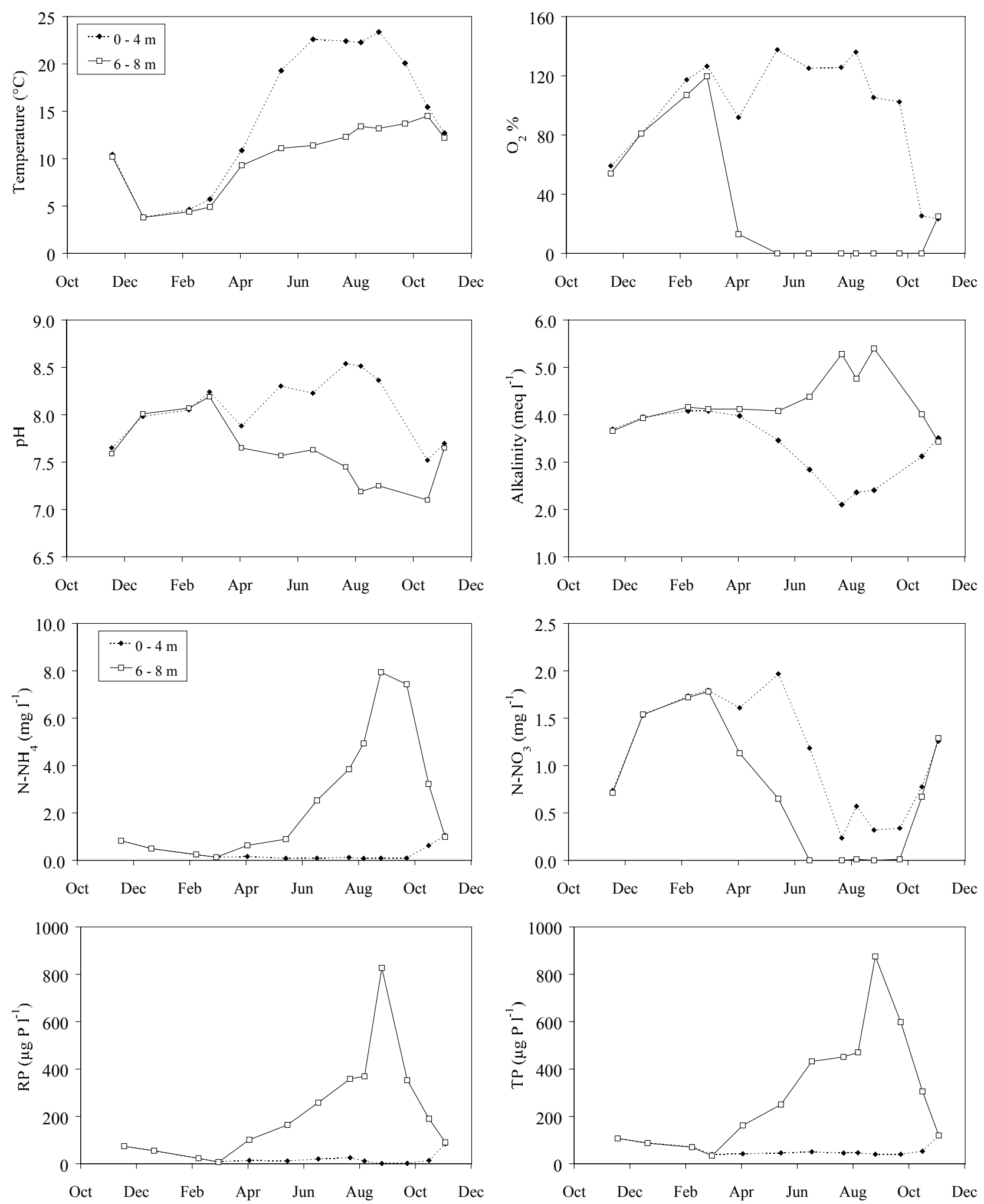

Fig. 4. Seasonal variations of some selected variables in epilimnion and hypolimnion of Lake Alserio in the period November 1999 November 2000. 
Tab. 5. Ionic composition of Lake Alserio water at three different samplings. Ionic concentrations: $\mu$ eq $1^{-1}$; conductivity: $\mu \mathrm{S} \mathrm{cm}^{-1} 20^{\circ} \mathrm{C}$.

\begin{tabular}{lccccccccccccc}
\hline & Water layer & $\mathrm{pH}$ & Cond. & $\mathrm{H}^{+}$ & $\mathrm{NH}_{4}^{+}$ & $\mathrm{Ca}^{++}$ & $\mathrm{Mg}^{++}$ & $\mathrm{Na}^{+}$ & $\mathrm{K}^{+}$ & $\mathrm{Alk}$. & $\mathrm{NO}_{3}^{-}$ & $\mathrm{SO}_{4}{ }^{=}$ & $\mathrm{Cl}^{-}$ \\
\hline March 2000 & $0-8 \mathrm{~m}$ & 8.47 & 407 & 0 & 8 & 3457 & 949 & 255 & 46 & 4146 & 125 & 358 & 360 \\
June 2000 & $0-3.5 \mathrm{~m}$ & 8.17 & 315 & 0 & 7 & 2344 & 892 & 254 & 40 & 3016 & 85 & 332 & 255 \\
& $6.5-8 \mathrm{~m}$ & 7.36 & 421 & 0 & 155 & 3543 & 913 & 257 & 54 & 4496 & 0 & 271 & 265 \\
\multirow{2}{*}{ November 2000 } & $0-8 \mathrm{~m}$ & 7.90 & 368 & 0 & 40 & 3251 & 776 & 204 & 49 & 3783 & 145 & 286 & 197 \\
\hline
\end{tabular}

Tab. 6. Mean chemical characteristics of the main tributaries and the outlet of Lake Alserio

\begin{tabular}{|c|c|c|c|c|c|c|c|c|c|}
\hline & $\mathrm{pH}$ & $\begin{array}{c}\text { Cond. } \\
\left(\mu \mathrm{S} \mathrm{cm}^{-1} 20^{\circ} \mathrm{C}\right)\end{array}$ & $\begin{array}{c}\text { Alk. } \\
\left(\mathrm{meq}^{-1}\right)\end{array}$ & $\begin{array}{l}\text { Total P } \\
\left(\mu \mathrm{g} \mathrm{l}^{-1}\right)\end{array}$ & $\begin{array}{c}\text { Total N } \\
\left(\mathrm{mg} \mathrm{N}^{-1}\right)\end{array}$ & $\begin{array}{c}\mathrm{N}-\mathrm{NO}_{3} \\
\left(\mathrm{mg} \mathrm{N} \mathrm{l}^{-1}\right)\end{array}$ & $\begin{array}{c}\mathrm{N}-\mathrm{NO}_{2} \\
\left(\mathrm{mg} \mathrm{N}^{-1}\right)\end{array}$ & $\begin{array}{c}\mathrm{N}-\mathrm{NH}_{4} \\
\left(\mathrm{mg} \mathrm{N} \mathrm{l}^{-1}\right)\end{array}$ & $\begin{array}{l}\text { Reactive Si } \\
\left(\mathrm{mg} \mathrm{Si}^{-1}\right)\end{array}$ \\
\hline Roggia dei Careggi & 8.24 & 447 & 4.09 & 179 & 5.79 & 5.43 & 0.08 & 0.12 & 4.00 \\
\hline $\begin{array}{l}\text { Roggia Ser } \\
\text { (Nov. } 1999 \text { - May 2000) }\end{array}$ & 7.9 & 609 & 5.1 & 527 & 12.1 & 5.8 & 0.9 & 4.8 & 5.60 \\
\hline $\begin{array}{l}\text { Roggia Ser } \\
\text { (Jun. } 2000 \text { - Dec. 2000) }\end{array}$ & 8.18 & 511 & 4.59 & 78 & 6.6 & 6.52 & 0.02 & 0.06 & 4.96 \\
\hline Roggia Parco Anzano & 8.08 & 541 & 5.04 & 52 & 4.41 & 3.92 & 0.03 & 0.09 & 4.62 \\
\hline Scolmatore & 8.0 & 543 & 5.37 & 168 & 5.19 & 3.36 & 0.16 & 1.17 & 5.02 \\
\hline Roggia Fiume & 8.26 & 420 & 4.09 & 118 & 5.71 & 4.48 & 0.09 & 0.50 & 4.10 \\
\hline Outlet & 7.91 & 369 & 3.55 & 66 & 2.51 & 1.44 & 0.04 & 0.22 & 1.35 \\
\hline
\end{tabular}

A second series of experiments was used a tank with a capacity of about 251 and a solution of $\mathrm{Ca}(\mathrm{OH})_{2}$ at a concentration of $50 \mathrm{~g} \mathrm{l}^{-1}$. During the period of lime addition $\mathrm{pH}$, total alkalinity, calcium, magnesium and reactive phosphorus were measured (Fig. 5): phosphorus concentrations went from an initial value of about $50 \mu \mathrm{g}$ $\mathrm{P}^{-1}$ to less than $1 \mu \mathrm{g} \mathrm{P}^{-1}$. Under the same experimental conditions, a solution of $\mathrm{CaCO}_{3}$ (concentration of $100 \mathrm{~g}$ $1^{-1}$ ) was added to a second tank. As can be seen in figure 5 , the phosphorus concentration, as well as $\mathrm{pH}$, alkalinity and calcium, remains quite steady while $\mathrm{CaCO}_{3}$ was added.

Similar results were reported on the liming experiments on eutrophic, hardwater lakes carried out in Canada, where both $\mathrm{Ca}(\mathrm{OH})_{2}$ and $\mathrm{CaCO}_{3}$ were used to precipitate phosphorus (Prepas et al. 1990; Babin et al. 1989): $\mathrm{Ca}(\mathrm{OH})_{2}$ proved to be more effective for removing both $\mathrm{P}$ and algae through calcite precipitation than direct applications with $\mathrm{CaCO}_{3}$, probably because dissociation of $\mathrm{Ca}(\mathrm{OH})_{2}$ into small, newly formed $\mathrm{CaCO}_{3}$ crystals provides a relatively large surface area for $\mathrm{P}$ adsorption (Babin et al. 1989; Murphy \& Prepas 1990).

\subsection{Liming - enclosures (August-September 2000)}

Before adding the lime to the enclosures, temperature, dissolved oxygen, $\mathrm{pH}$ and conductivity were measured in the water column, so that the situation inside the enclosures could be compared to that of the lake. Dissolved oxygen concentrations were slightly higher in the lake water, but none of the other variables showed significant differences inside and outside the enclosures. Lake water was thermally stratified, with the thermocline between 3 and $4 \mathrm{~m}$. Maximum temperature $\left(26^{\circ} \mathrm{C}\right.$ at $\left.0 \mathrm{~m}\right)$ was such that maximum difference be- tween surface and bottom waters (about $6{ }^{\circ} \mathrm{C}$ ), was recorded in mid August. The water layer below $4 \mathrm{~m}$ showed steep gradients for all the chemical variables; anoxic conditions were found below $4.5 \mathrm{~m}$.
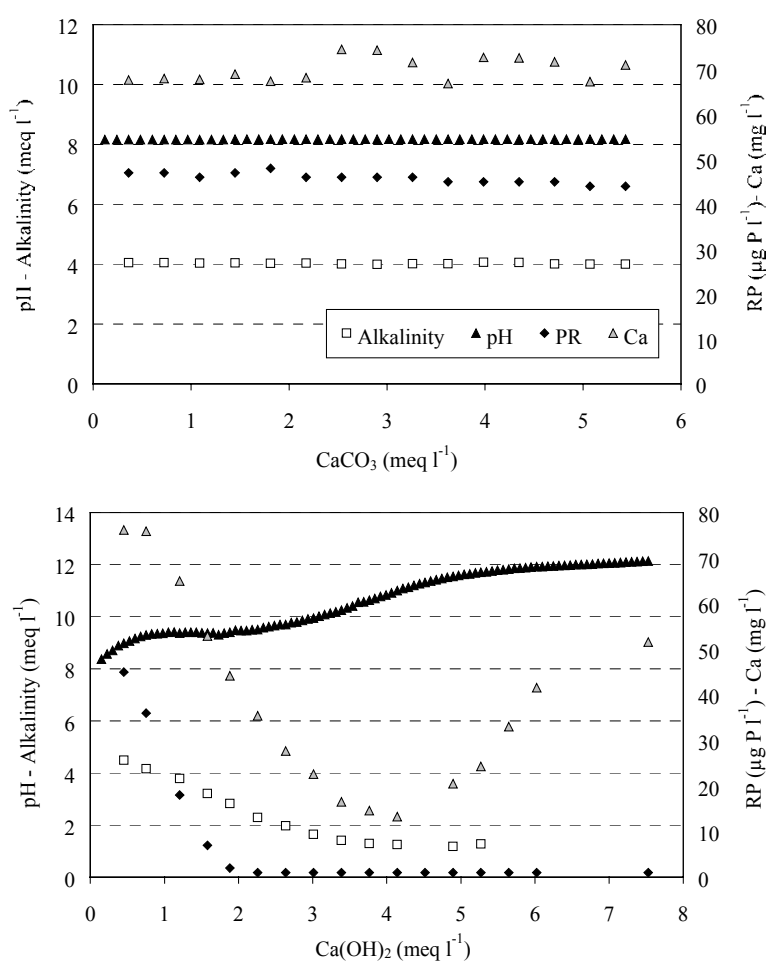

Fig. 5. Results of the laboratory experiments on Lake Alserio water: $\mathrm{pH}$, alkalinity, calcium and reactive phosphorus (RP) measured during titration with $\mathrm{CaCO}_{3}$ (above) and $\mathrm{Ca}(\mathrm{OH})_{2}$ (below). Time between consecutive additions: 1 minute; titrated volume: $18 \mathrm{l} ; \mathrm{CaCO}_{3}$ concentration: $100 \mathrm{~g} \mathrm{l}^{-1}$; $\mathrm{Ca}(\mathrm{OH})_{2}$ concentration: $50 \mathrm{~g} \mathrm{l}^{-1}$. 
Values of the main chemical variables recorded during the experiment at 0,2 and $4 \mathrm{~m}$ in the enclosure treated with $\mathrm{Ca}(\mathrm{OH})_{2}$ are shown in figure 6 . Lime additions impacted on $\mathrm{pH}$, conductivity, alkalinity and calcium. $\mathrm{pH}$ at $0 \mathrm{~m}$, after the $\mathrm{Ca}(\mathrm{OH})_{2}$ addition, increased from 8.2 to 9.4 , while conductivity dropped from 270 to $160 \mu \mathrm{S} \mathrm{cm}^{-1}$, as a consequence of calcium carbonate precipitation. In contrast, at a depth of $4.0 \mathrm{~m}$, in the two weeks following the addition, $\mathrm{pH}$ dropped to below 8.0 again and conductivity increased progressively to a final value of $270 \mu \mathrm{S} \mathrm{cm}^{-1}$ (23 August).

Alkalinity and calcium concentrations in the deep water, after a marked decrease (from 2700 to 1100-1200 $\mu$ eq $1^{-1}$ and from about 2000 to $500 \mu$ eq $1^{-1}$, respectively), returned to their initial values.

These variations were caused by partial dissolution of the precipitating calcium carbonate as it comes into contact with the deep water, characterized by low $\mathrm{pH}$ and high $\mathrm{CO}_{2}$ saturation. At the last sampling, about 1 month after the lime addition, $\mathrm{pH}$, conductivity, alkalinity and calcium showed similar values at the different depths: 9.5, $188 \mu \mathrm{S} \mathrm{cm}^{-1}, 1550 \mu \mathrm{eq} \mathrm{l}^{-1}$ and $980 \mu \mathrm{eq} \mathrm{l}^{-1}$, respectively (Fig. 6).

Low in-lake phosphorus concentrations present in the summer, both in reactive and total form, hindered the evaluation of the efficiency of lime to precipitate phosphorus. However, the consequence of $\mathrm{CaCO}_{3}$ precipitation is illustrated with trends in phosphorus concentrations during the experiment (Fig. 6): after the addition of $\mathrm{Ca}(\mathrm{OH})_{2}$ to the enclosure, total phosphorus concentrations dropped from 50 to 31 and from 68 to 29 $\mu \mathrm{g} \mathrm{P}^{-1}$ at 2 and $4 \mathrm{~m}$, respectively (unfiltered sample), then $\mathrm{P}$ gradually accumulated in the deep water (to 90 $\mu \mathrm{g} \mathrm{P}^{-1}$ at $\left.4.0 \mathrm{~m}\right)$. In September the values were similar

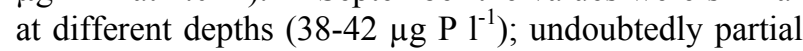
dissolution of previously-formed $\mathrm{CaCO}_{3}$ contributed to phosphorus release and to this concentration increased observed some weeks after the liming.

Nitrogen compounds (nitrate, ammonium and total nitrogen) did not vary as a result of the lime treatment. Total $\mathrm{N}$ concentrations remained stable $(0.8-1.2 \mathrm{mg} \mathrm{N}$ $1^{-1}$ ) during the experiment (Fig. 6). Reactive silica concentrations varied between surface and deep water (0.10.3 and $0.8-1.2 \mathrm{mg} \mathrm{Si}^{-1}$, respectively) until the end of August, then they were homogeneous in the water column in September (about $0.3 \mathrm{mg} \mathrm{Si}^{-1}$ ). In the enclosure, values at $4.0 \mathrm{~m}$ increased at the end of August (from 0.9 to $1.6 \mathrm{mg} \mathrm{Si}^{-1}$ ) and then they returned to 0.5 $\mathrm{mg} \mathrm{Si} 1^{-1}$ in September (Fig. 6).

Inside the enclosure, transparency changed from about $2 \mathrm{~m}$ to $0.5 \mathrm{~m}$ because of suspended $\mathrm{CaCO}_{3}$ crystals, then increased to a maximum value of $3.0 \mathrm{~m}$, markedly higher than outside the enclosures. This change in light penetration was due to sedimentation of phytoplankton cells with the precipitating $\mathrm{CaCO}_{3}$.

\subsection{Liming - enclosures (November-December 2000)}

The second liming experiment was performed in late autumn, when phosphorus concentrations were higher than in summer (40 and $70 \mu \mathrm{g} \mathrm{P}^{-1}$ as RP and TP, respectively) and distributed equally throughout the water column. Owing to a period of heavy rainfall in the Lake Alserio area, water level increased and one of the enclosures had water spill into it from outside. Due to this the experiment was interrupted and then restarted some days later, with only one enclosure being used for the test and the lake as control. Also on this occasion, before the lime addition, profiles of $\mathrm{pH}$, conductivity, temperature and dissolved oxygen were made, to evaluate the initial conditions inside and outside the enclosure. Lake water was not stratified and temperature was the same through the water column $\left(8.7-9.0^{\circ} \mathrm{C}\right)$, while dissolved oxygen concentrations were between 8.0 and $8.6 \mathrm{mg} \mathrm{l}^{-1}$. Concentrations of the chemical variables were similar at the three sampling depths $(0,3$ and $5 \mathrm{~m})$; for this reason, results are shown as mean values in the water column (Fig. 7).

$\mathrm{Ca}(\mathrm{OH})_{2}$ addition caused a marked increase in $\mathrm{pH}$, from 7.9 to 8.7 while alkalinity and calcium concentrations decreased (from 3600 to $1700 \mu \mathrm{eq} \mathrm{l}^{-1}$ and from 3200 to $1400 \mu \mathrm{eq} 1^{-1}$, respectively) (Fig. 7). The effect of $\mathrm{CaCO}_{3}$ precipitation is evident also in the trend of conductivity, which went from 360 to $210 \mu \mathrm{S} \mathrm{cm} \mathrm{cm}^{-1}$. RP decreased from an initial value of $40 \mu \mathrm{g} \mathrm{P}^{-1}$ to $3-5 \mu \mathrm{g} \mathrm{P}$ $\mathrm{I}^{-1}$ in the two weeks following the lime addition, and then increased to $11 \mu \mathrm{g} \mathrm{P} \mathrm{^{-1 }}$ in January. TP dropped from $69 \mu \mathrm{g} \mathrm{P}^{-1}$ to $16-18 \mu \mathrm{g} \mathrm{P}^{-1}$, while the January concentration was $25 \mu \mathrm{g} \mathrm{P} \mathrm{l^{-1 }}$ (Fig. 7). No variation emerged in the other chemicals measured which they remained fairly constant during the experiment (e.g. TN, Fig. 7).

\section{DISCUSSION}

\subsection{Present trophic level of the lake}

The hydro-chemical and biological investigations carried out between November 1999 and December 2000 suggest that the present condition of Lake Alserio is between eutrophy and hypereutrophy. We can draw this conclusion by applying the O.E.C.D. statistical model, which considers in-lake phosphorus and chlorophyll- $a$ concentrations (O.E.C.D. 1982). Following this approach, mean annual phosphorus value of $80 \mu \mathrm{g} \mathrm{P}^{-1}$ for Lake Alserio indicates a probability of $65 \%$ and $15 \%$ for the classes of eutrophy and hypereutrophy, respectively; the remaining $20 \%$ is for the mesotrophy class. The phosphorus value at winter overturn $(110 \mu \mathrm{g}$ $\mathrm{P}^{-1}$ ) gives a similar results. Chlorophyll- $a$ values, measured in the summer period, range from 30 to $40 \mu \mathrm{g}$ $1^{-1}$, with a peak of $43 \mu \mathrm{g} \mathrm{l}^{-1}$ in August, decreasing to 6 $\mu \mathrm{g} \mathrm{l}^{-1}$ in October. These concentrations are in agreement with those of phosphorus and put Lake Alserio in the eu-hypereutrophic class. 

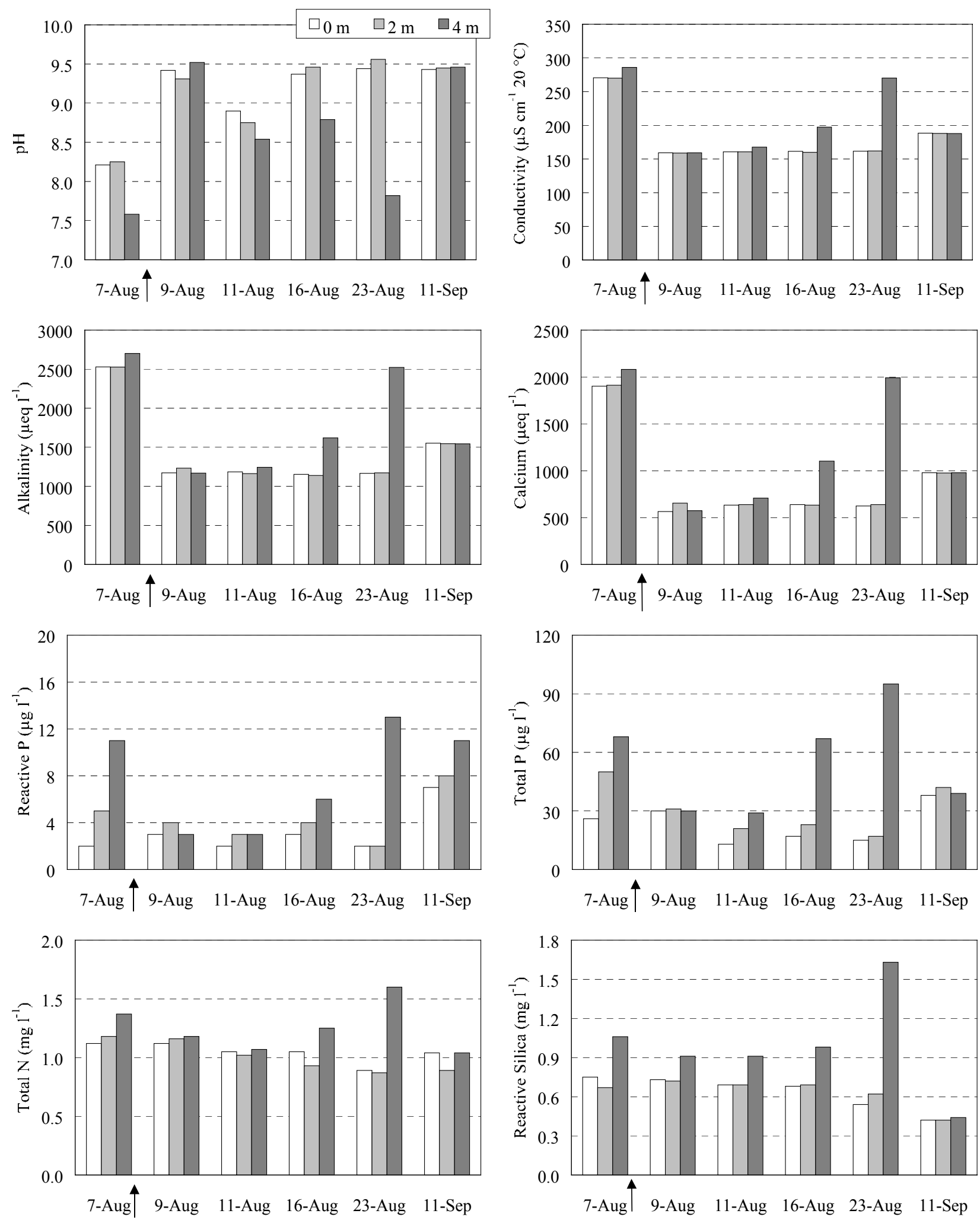

Fig. 6. Trend of the main chemical variables at 0,2 and $4 \mathrm{~m}$ during the first liming experiment in the enclosure treated with $\mathrm{Ca}(\mathrm{OH})_{2}$. The arrow marks the $\mathrm{Ca}(\mathrm{OH})_{2}$ addition. 

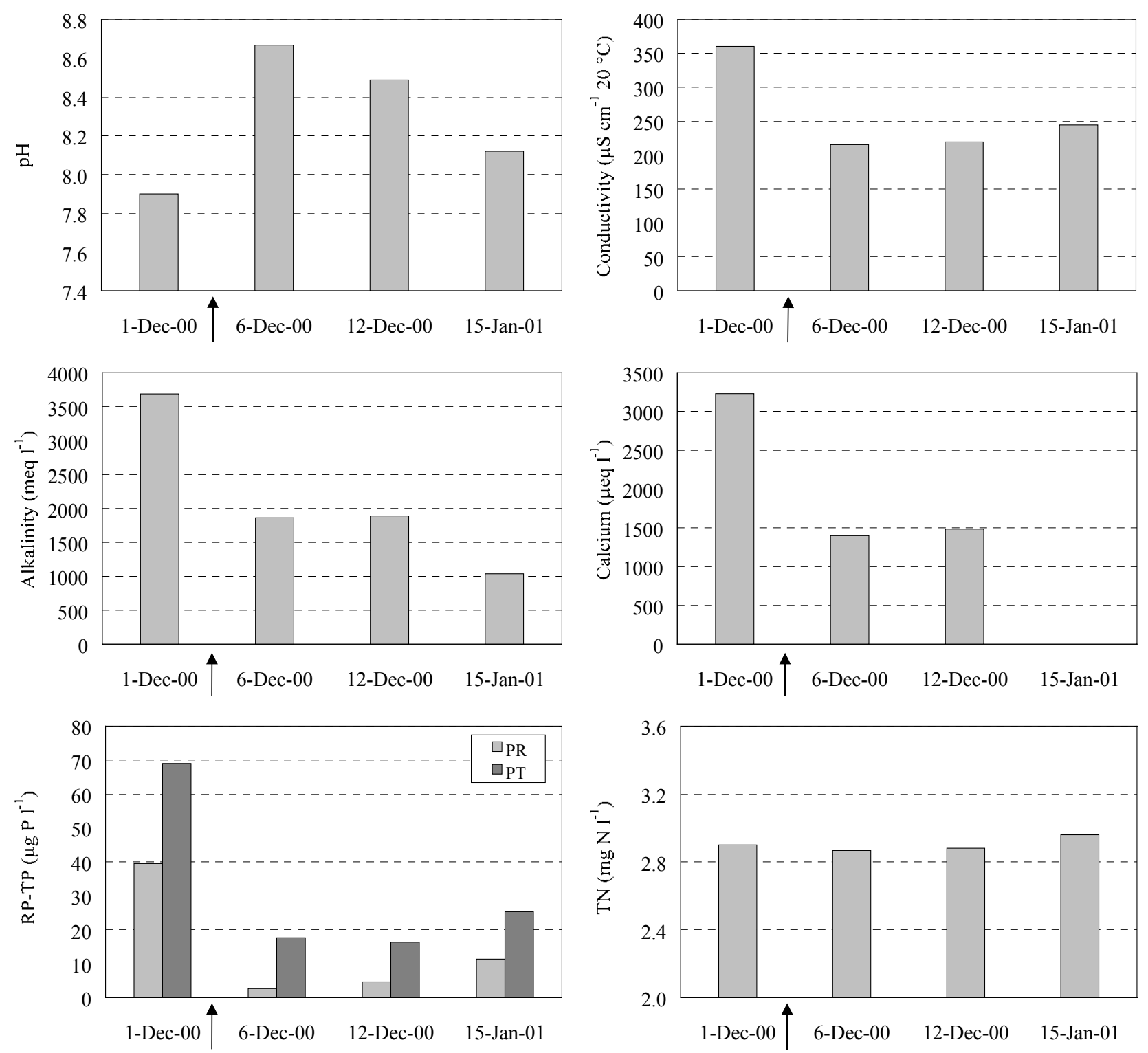

Fig. 7. Trend of the main chemical variables (mean values on the water column) during the second liming experiment in the enclosure treated with $\mathrm{Ca}(\mathrm{OH})_{2}$. The arrow marks the $\mathrm{Ca}(\mathrm{OH})_{2}$ addition.

These estimates of the present trophic level of Lake Alserio are consistent with the seasonal cycles of some chemical variables:

1) anoxic hypolimnetic waters for a prolonged period (May - October) during summer stratification, with production of reducing compounds such as $\mathrm{H}_{2} \mathrm{~S}$ and $\mathrm{NH}_{4}$ (concentrations in the deep waters ranged from 7 to $8 \mathrm{mg} \mathrm{N}^{-1}$ );

2) high phosphorus release rates from the sediments (summer phosphorus concentrations in the deep water close to $1 \mathrm{mg} \mathrm{P}^{-1}$ ), typical of environments which have been eutrophic for several years.

A different approach to evaluate the expected trophic condition of a lake considers mean phosphorus concentrations of inflowing waters and the theoretical renewal time of the water $\left(\tau_{\mathrm{w}}\right)$, as set out in the synthesis model (O.E.C.D. 1982) (Fig. 8).

With a $\tau_{\mathrm{w}}$ value of 0.33 years, we estimated that to keep Lake Alserio oligotrophic, inflowing phosphorus concentrations from the tributaries should be lower than $20 \mu \mathrm{g} \mathrm{P} \mathrm{l}^{-1}$; average inflowing phosphorus values from 20 to $40 \mu \mathrm{g} \mathrm{P}^{-1}$ resulted in mesotrophic conditions, while with inflowing values over $40 \mu \mathrm{g} \mathrm{P}^{-1}$ the most probable trophic condition for the lake is eutrophy. Present TP concentrations of the tributaries are much higher than $40 \mu \mathrm{g} \mathrm{P} \mathrm{1-1} \mathrm{(Tab.} \mathrm{6,} \mathrm{Fig.} \mathrm{8)} \mathrm{and,} \mathrm{in} \mathrm{spite} \mathrm{of}$ the sewage diversion, they are too high to permit Lake Alserio to return to mesotrophic conditions. This is also 


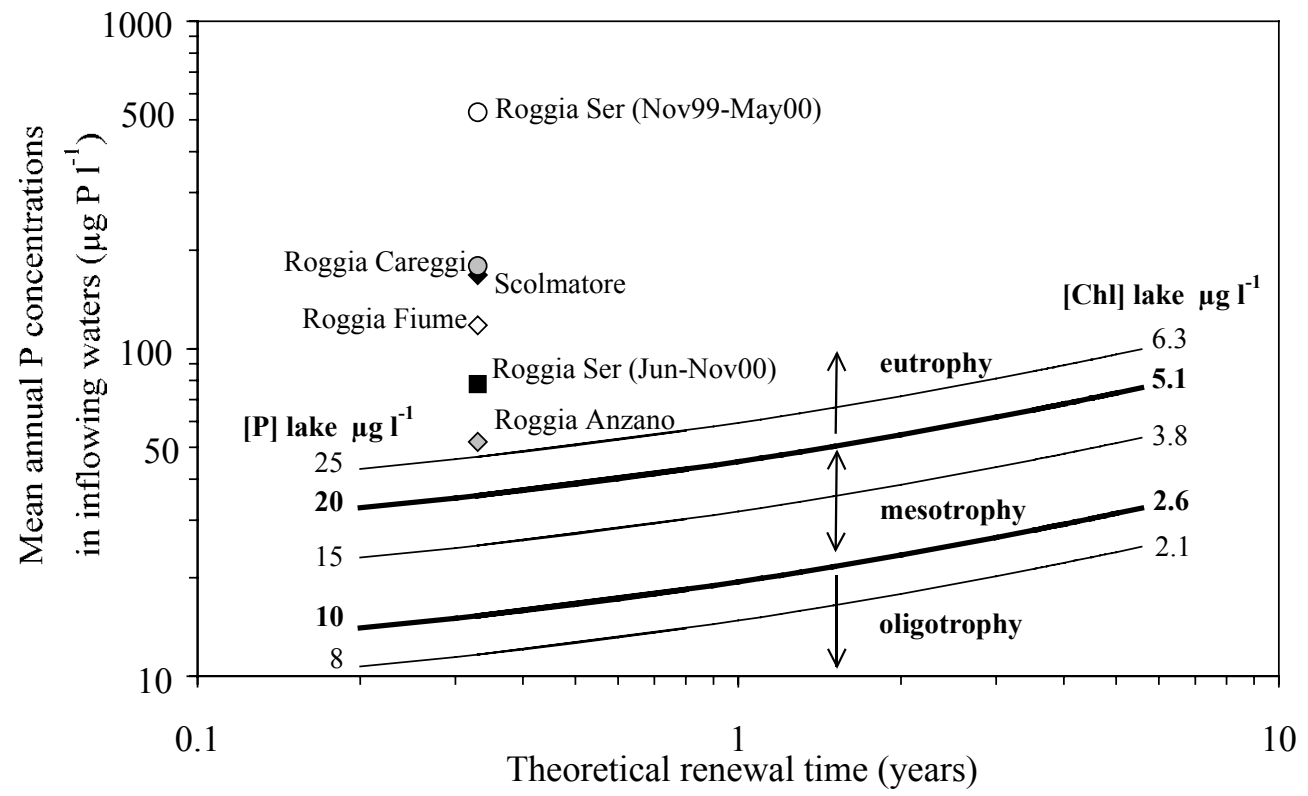

Fig. 8. OECD model applied to Lake Alserio.

true for Roggia Ser, one of the main tributaries to the lake, even after the diversion of most of the sewage from its watershed to the treatment plant. However it must be pointed out that the O.E.C.D. approach does not take account for $\mathrm{P}$ release $\mathrm{P}$ from the sediments, which constitutes an important additional load to the lake.

\subsection{Calcite precipitation in Lake Alserio}

The chemical and biological processes going on in Lake Alserio are strongly influenced by inorganic carbon-calcite equilibria. High concentrations of bicarbonate, carbonate and calcium, and the high productivity of Lake Alserio produce the conditions for calcium carbonate precipitation in the epilimnion in spring and summer, as a consequence of $\mathrm{CO}_{2}$ uptake and $\mathrm{pH}$ and carbonate increase from photosynthesis. These processes are common in hardwater lakes and are accentuated by an increased productivity (Wetzel 1972; Kelts \& Hsu 1978; Koschel 1983). In Lake Alserio calcite precipitation is induced by increased $\mathrm{pH}$ in spring and results in decrease alkalinity and calcium values in surface water beginning in April. In August alkalinity values in surface waters are reduced to half those at spring overturn. Carbonate equilibrium, and in particular calcite precipitation, can be better understood using the $\Omega$ index (Fig. 9), calculated from the ratio of the ionic product of calcium and carbonate present in water and the solubility product of $\mathrm{CaCO}_{3}$. For Lake Alserio $\Omega$ values, calculated for different depths, increased in the winter months up to 5 to 6 in March; then, as a consequence of precipitation, decreased to 2 to 3 (Fig. 9). Strong oversaturation of calcite in lake water, without precipitation, has been described in several lakes (e.g. Proft \& Stutter 1993; Stabel 1986; Schroeder et al. 1983).

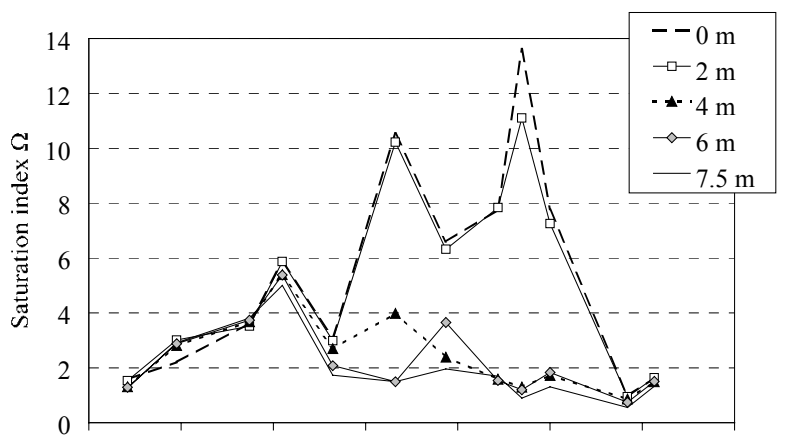

Oct-99 Dec-99 Feb-00 Apr-00 Jun-00 Aug-00 Oct-00 Dec-00

Fig. 9. Seasonal variations of the saturation index $\Omega$ at different depths in Lake Alserio.

During summer stratification two distinct situations were present: in epilimnetic water ( 0 to $2 \mathrm{~m}$ ) peak values were recorded in May and in August, while in the deep water the index values, which were always below 4 , decreased to 1 , as a consequence of over-saturation of $\mathrm{CO}_{2}$ and decreased $\mathrm{pH} . \mathrm{CO}_{2}$ supply is determined by the anoxic conditions which characterised the hypolimnion during stratification. Mixing in November lead again to index values of 1 to 2 in the whole water column (Fig. 9). For most of the year water in the epilimnion was over-saturated with $\mathrm{CaCO}_{3}$. The importance of re-dissolution of calcite in anoxic water was noted in our first liming experiment. However, although there was partial re-dissolution, most calcite remains in the sediments: in Lake Alserio 70 to $80 \%$ of their total dry weight is composed of $\mathrm{CaCO}_{3}$ (Guilizzoni et al. 1982). 
Tab. 7. Precipitation of calcite and phosphorus in laboratory and lake experiments.

\begin{tabular}{|c|c|c|c|c|c|c|c|c|c|}
\hline & $\begin{array}{l}\text { volume } \\
\left(\mathrm{m}^{3}\right)\end{array}$ & $\begin{array}{l}\text { add. } \mathrm{Ca}(\mathrm{OH})_{2} \\
\quad\left(\mathrm{meq} \mathrm{l}^{-1}\right)\end{array}$ & $\begin{array}{l}\text { add. Alk. } \\
\left({\left.\text { meq } 1^{-1}\right)}^{-1}\right.\end{array}$ & $\begin{array}{c}\Delta \mathrm{P} \\
\left(\mu \mathrm{g} \mathrm{l}^{-1}\right)\end{array}$ & $\begin{array}{c}\Delta \mathrm{P} \\
\left(\mu \mathrm{mol} \mathrm{l}{ }^{-1}\right)\end{array}$ & $\begin{array}{c}\Delta \text { Alk } \\
\left(\mathrm{mmol} \mathrm{l}^{-1}\right)\end{array}$ & $\begin{array}{c}\Delta \mathrm{Ca} \\
\left(\mathrm{mmol} \mathrm{l}^{-1}\right)\end{array}$ & $\begin{array}{c}\mathrm{CaCO}_{3} \\
\left(\mu \mathrm{mol} \mathrm{P} \mathrm{mmol}{ }^{-1}\right)\end{array}$ & $\begin{array}{l}\mathrm{CaCO}_{3} \\
\left(\mathrm{~g} \mathrm{P} \mathrm{g}^{-1}\right)\end{array}$ \\
\hline Laboratory 1 & 0.02 & 2.10 & 2.10 & 46 & 1.48 & 3.98 & 1.90 & 0.78 & 242.4 \\
\hline Liming 1 & 35.34 & 1.48 & 1.48 & 8 & 0.27 & 2.52 & 1.24 & 0.22 & 67.4 \\
\hline Liming 2 & 42.41 & 2.31 & 2.31 & 53 & 1.71 & 4.11 & 2.03 & 0.84 & 261.0 \\
\hline
\end{tabular}

\subsection{Liming experiments}

The liming experiments in enclosures in August reproduced the $\mathrm{CaCO}_{3}$ precipitation process which occurs naturally in lake water; the $\mathrm{Ca}(\mathrm{OH})_{2}$ used for the treatment did not modify the ionic content of the lake water. As a consequence of liming, $\mathrm{pH}$ and calcium values increased and the solubility product of calcite was exceeded, so that $\mathrm{CaCO}_{3}$ precipitated. The $\Omega$ values were different in the two liming experiments: in summer chemical stratification determined a clear difference between the values at the surface, with an index value ranging from 4 to 14 , and those in the deep water, where the index value varied from 1 to 8 . In the liming carried out during autumnal turnover, the $\Omega$ values were homogeneous between 2 and 3 .

$\Omega$ values did not indicate the date of initiation nor the intensity of calcite precipitation. The discrepancy between thermodynamic and actual calcium and carbonate concentrations in lake water is given by Kurz (2000) and Dittrich (1997) as follows: the index is calculated from variables which are mean values from the designated water layers; conditions may differ in the microscopic layer between the algal cell wall and surrounding water. At this interface, during photosynthetic activity, the degree of over-saturation of $\mathrm{CaCO}_{3}$ can be higher than that recorded in the whole water body. Picoplankton cells (dimensions between 0.2 and $2 \mu \mathrm{m}$ ) are particularly efficient at creating such conditions, making it possible to reach and exceed the energy barrier needed to induce the precipitation process (Dittrich 1997; Kurz 2000).

The stoichiometry of the co-precipitation of phosphorus with calcite in laboratory and lake experiments is shown in table 7. The concentration of calcium hydroxide, expressed both as calcium and alkalinity addition, takes into account the volumes of solution treated. $\Delta$ values for phosphorus, alkalinity and calcium are calculated from initial, added and final concentrations as:

$$
\Delta=\mathrm{C}_{\text {initial }}+\mathrm{C}_{\text {added }}-\mathrm{C}_{\text {final }}
$$

$\Delta$ represents the amount of substance precipitated and hence subtracted from solution. Comparison between alkalinity and calcium precipitated is close to the stoichiometric ratio of 1 to 2 (molar concentrations). The amount of $\mathrm{P}$ precipitated is $0.6-0.7 \mu \mathrm{M}$ per $\mathrm{mM}$ of $\mathrm{CaCO}_{3}$, or $0.02 \mathrm{~g}$ of $\mathrm{P}$ per $\mathrm{g}$ of $\mathrm{CaCO}_{3}$ for both laboratory experiments and the second lake experiment.
Lower amounts of $\mathrm{P}$ eliminated per unit of calcite in the first lake liming, which was performed when $\mathrm{P}$ concentrations in the lake were relatively low $\left(48 \mu \mathrm{g} \mathrm{P}^{-1}\right)$, so that $\Delta \mathrm{P}$ was also low $\left(8 \mu \mathrm{g} \mathrm{P}^{-1}\right.$, Tab. 7).

\section{CONCLUSIONS}

At present Lake Alserio is eutrophic. Partial diversion of sewage resulted in a progressive decrease of $\mathrm{P}$ concentrations in the lake water, from mean values of over $150 \mu \mathrm{g} \mathrm{P}^{-1}$ in the 80 s to values between 50 and $100 \mu \mathrm{g} \mathrm{P}^{-1}$ in the 90s (Gerletti \& Marchetti 1977, Chiaudani \& Premazzi 1992; Negri et al. 1995, 1996, 1997; Rogora et al. 2001), but this improvement did not influence the biological productivity of the lake. Studies on the tributaries showed that external load is still too high to permit the lake water to become mesotrophic, as the goal of the recovery measures. A mean P concentration of below $40 \mu \mathrm{g} \mathrm{P} \mathrm{l}^{-1}$ would be required in the inflowing water, while present values are between 50 and $180 \mu \mathrm{g} \mathrm{P}^{-1}$. So sewage diversion must be completed to improve lake condition. As well as the external P load, the internal load must also be considered, as indicated by the very high $\mathrm{P}$ concentrations (up to $800 \mu \mathrm{g} \mathrm{P}^{-1}$ ) in the hypolimnion. Part of this hypolimnetic phosphorus reaches the epilimnion during autumn overturn, thus delaying lake recovery.

Liming the lake to precipitate phosphorus as well as other components of the recovery project (e.g. the withdrawal of hypolimnetic water) have potential to reduce negative effects of eutrophication. However their use in the case of Lake Alserio must be carefully. Liming has been successfully used in other water bodies to ameliorate water quality (Murphy \& Prepas 1990; Dittrich et al. 1997; Ghadouani et al. 1998; Koschel 1997), to improve the quality of drinking water (Prepas et al. 1997) and even to eliminate the effects of cyanobacterial toxins (Angeline et al. 1995a, b, 1997). The liming experiments performed on Lake Alserio confirm that $\mathrm{P}$ is removed from the water, but the experimental conditions must be planned to maximize $P$ precipitated and minimize re-dissolution of calcite. For the first goal, lime should be added when $\mathrm{P}$ concentrations are high, i.e. during autumn-winter overturn over the whole water column, or during thermal stratification in hypolimnion. The re-dissolution of calcite in anoxic water could be reduced by increased $\mathrm{Ca}(\mathrm{OH})_{2}$ added to compensate for excess $\mathrm{CO}_{2}$, or adding lime in more phases (i.e. autumnwinter and summer stratification). Addition of $\mathrm{Ca}(\mathrm{OH})_{2}$ 
to lake water had no negative effects on the biota of Lake Alserio, but care must be taken to keep $\mathrm{pH}$ below 9.5 to avoid toxic effects due to free ammonia (Giussani et al. 1976). Variations induced in the ionic composition of the water must have no impact on biological processes; it must be emphasised that, in spite of the addition of calcium oxide, calcium and alkalinity content of the water is lower after liming, because of calcite precipitation.

In conclusion, from a technical point of view it would be possible to lime Lake Alserio to accelerate its recovery. However specific procedures for the process are still to be defined, and a cost-benefit analysis is needed. Nevertheless, before this or any other remedial procedures to reduce internal $\mathrm{P}$ load, sewage diversion must be completed.

\section{ACKNOWLEDGMENTS}

The LIFE Project on Lake Alserio (LIFE99NAT/ IT/006235) is funded by the European Commission, DG XI, Regione Lombardia and Consorzio Parco Valle del Lambro. We are grateful to Ellie. E. Prepas, University of Alberta, and Maria Dittrich, EAWAG, Kastanienbaum, for good advice and comments on the manuscript.

\section{REFERENCES}

Angeline, K., Y. Lam, \& E.E. Prepas. 1997. In situ evaluation of options for chemical treatment of hepatotoxic cyanobacterial blooms. Can. J. Fish. Aquat. Sci., 54: 1736-1742.

Angeline, K., Y. Lam, P. M. Fedorak \& E.E. Prepas. 1995b. Biotransformation of the Cyanobacterial Hepatotoxin Microcystin-LR, as determined by HPLC and protein phosphatase bioassay. Environ. Sci. Technol., 28: 242-246.

Angeline, K., Y. Lam, E.E. Prepas, D. Spink and S.E. Hrundey. 1995a. Chemical control of hepatotoxic phytoplancton blooms: implication for human health. Wat. Res., 29: 1845-1854.

A.P.H.A., A.W.W.A., W.P.C.F. 1981. Standard methods for the examination of water and wastewater. Am. Publ. Health Ass., Washington.

A.P.H.A., A.W.W.A., W.P.C.F. 1992. Standard methods for the examination of water and wastewater. Am. Publ. Health Ass., Washington.

A.P.H.A, A.W.W.A. \& W.E.F. 1995. Standard methods for the examination of water and wastewater. Am. Pub. Health Ass., Washington.

Babin, J., E.E. Prepas, T.P. Murphy \& H.R. Hamilton. 1989. A test of the effects of lime on algal biomass and total phosphorus concentration in Edmonton stormwater retention lakes. Lake Reserv. Manage., 5: 129-135.

Bonomi, G., C. Bonacina \& I. Ferrari. 1967. Caratteristiche chimiche, plancton e benton nel quadro evolutivo recente dei laghi briantei. Mem. Ist. ital. Idrobiol., 21: 241-287.

Chiaudani, G. \& G. Premazzi. 1992. I laghi briantei. Situazione trofica e soluzioni scientifiche per il risanamento. Commissione delle Comunità Europee, EUR 14548 IT: $212 \mathrm{pp}$.

de Bernardi, R., G. Giussani, P. Guilizzoni \& R. Mosello. 1985. Indagine conoscitiva per una caratterizzazione limnologica dei Piccoli Laghi Lombardi. Documenta Ist. ital. Idrobiol., 8: 205 pp.
Dittrich, M., T. Dittrich, I. Sieber \& R. Koschel. 1997. A balance analysis of phosphorus elimination by artificial calcite precipitation in a stratified hardwater lake. Wat. Res., 31: 237-248.

E.P.A. 1986. Dissolved sodium, ammonium, potassium, magnesium and calcium in wet deposition by chemical suppressed ion chromatography. U.S. Environmental Protection Agency, Washington.

Fresenius W., K.E. Quentin W. Schneider (Eds). 1988. Water Analysis. Springer-Verlag Berlin: 804 pp.

Gerletti, M. \& R. Marchetti. 1977. Indagini sui laghi della Brianza. I.R.S.A. Quaderni, 19: 358 pp.

Ghadouani, A., B. Pinel-Alloul, Y. Zhang \& E.E. Prepas. 1998. Relationship between zooplankton community structure and phytoplankton in two lime-treated eutrophic hardwater lakes. Freshwat. Biol., 39: 775-790.

Giussani, G., I. Borroni \& E. Grimaldi. 1976. Role of un-ionized ammonia in predisposing gill apparatus of Alburnus alburnus alborella to fungal and bacterial diseases. Mem. Ist. ital. Idrobiol., 33: 161-175.

Golterman, H.L., R.S. Clymo \& M.A.M. Ohnstand. 1978. Methods for physical and chemical analysis of fresh waters. I.B.P. Handbook No. 8, Blackwell, Oxford: 213 pp.

Gran, G. 1952. Determination of the equivalence point in potentiometric titration II. Analyst, 77: 661-6171.

Guilizzoni, P., G. Bonomi, G. Galanti \& D. Ruggiu. 1982. Basic trophic status and recent development of some Italian lakes as revealed by plant pigments and other chemical compoud in sediment core. Mem. Ist. ital. Idrobiol., 40: 79-98.

Kelts, K. \& K.J. Hsü. 1978. Freshwater carbonate sedimentation. In A. Lerman (Ed.), Lakes chemistry geology physics. Springer-Verlag, Berlin: 295-323.

Köppen, W. \& A. Wegener. 1940. Die Klimate der geologischen Vorzeit. Verlag von Gebruder Borntraeger, Berlin: $256 \mathrm{pp}$.

Koschel, R.H. 1997. Structure and function of pelagic calcite precipitation in lake ecosystems. Verh. int. Ver. Limnol., 26: 343-349.

Koschel, R., J. Benndorf, G. Proft \& F. Recknagel. 1983. Calcite precipitation as a natural control mechanism of eutrophication. Arch. Hydrobiol., 98: 380-408.

Kurz, P. 2000. Calcium carbonate biomineralisation in freshwater picoplancton. Diploma thesis. EAWAG, Limnological Research Center, Kastanienbaum, Switzerland: $62 \mathrm{pp}$.

Murphy, T.P. \& E.E. Prepas. 1990. Lime treatment of hardwater lakes to reduce eutrophication. Verh. int. Ver. Limnol., 24: 327-334.

Negri, A., L. Colzani, F. Ghilardi, V. Miano, C. Monti, P. Arlati, A. Carlozzo \& C. Sala. 1995. Censimento dei corpi idrici della Provincia di Como. Prov. № 1934 del 1-101992: 69 pp.

Negri, A., L. Colzani, F. Ghilardi, V. Miano, C. Monti, P. Arlati, A. Carlozzo \& C. Sala. 1996. Censimento dei corpi idrici della Provincia di Como. Prov. No 1934 del 1-101992: $60 \mathrm{pp}$.

Negri, A., L. Colzani, F. Ghilardi, V. Miano, C. Monti, P. Arlati, A. Carlozzo \& C. Sala. 1997. Censimento dei corpi idrici della Provincia di Como. Prov. № 1934 del 1-101992: $58 \mathrm{pp}$.

O.E.C.D. 1982. Eutrophication of waters. Monitoring, assessment and control. O.E.C.D. Publication $\mathrm{N}^{\circ} 42077$, Paris: 154 pp.

Pagnotta, A. \& R. Passino. 1992. Research programmes in limnological field in Italy and effects of the current environmental legislation. In: Guilizzoni, P., G. Tartari \& G. Giussani (Eds), Limnology in Italy. Mem. Ist. ital. Idrobiol., 50: 19-28.

Prepas, E.E., T.P. Murphy, W.P. Dinsmore, J.M. Burke, P.A. Chambers \& S. Reedyk. 1997. Lake management based on 
lime application and hypolimnetic oxygenation: The experience in eutrophic hardwater lakes in Alberta. In: Barica, J. \& R.J. Allan (Eds), Aquatic ecosystem Restoration. 32(2): 273-293

Prepas, E.E., R.P. Murphy, J.M. Crosby, D.T. Walty, J.T. Lim, J. Babin \& P.A. Chambers. 1990. Reduction of phosphorus and chlorophyll- $a$ concentrations following $\mathrm{CaCO}_{3}$ and $\mathrm{Ca}(\mathrm{OH})_{2}$ additions to hypereutrophic Figure Eight Lake, Alberta. Environ. Sci. Technol., 24: 1252-1258.

Proft, G. \& E. Stutter. 1993. Calcite precipitation in Hard Water Lakes in Calculation and Experiment. Int. Revue ges. Hydrobiol., 78:177-199.

Provini, A., R. Marchetti \& G. Tartari. 1992. The Italian lakes: trophic status and remedial measures. In: Guilizzoni, P., G. Tartari \& G. Giussani (Eds), Limnology in Italy. Mem. Ist. ital. Idrobiol., 50: 147-169.

Rogora, M., S. Arisci \& L. Garibaldi. 2001. Attuale livello trofico del Lago di Alserio e prospettive per il suo risanamento. Atti A.I.O.L., 14: 379-388.

Received: September 2001

Accepted: January 2002
Schröder, H.G., H. Windolph \& J. Schneider. 1983. Bilanzierung der biogenen Karbonatproduktion eines oligotrophen Sees. Arch. Hydrobiol., 97: 356-372.

Stabel, H.H. 1986. Calcite precipitation in Lake Costance: chemical equilibrium, sedimentation and nucleation by algae. Limnol. Oceanogr., 31(5): 1081-1093.

Stumm, W. \& J.J. Morgan. 1981. Aquatic chemistry. Wiley and Sons, New York: $780 \mathrm{pp}$.

Valderrama, J.C. 1977. Methods used by the Hydrographic Department of the National Board of Fisheries. Goteborg, Sweden.

Valderrama, J.C. 1981. The simultaneous analysis of total nitrogen and total phosphorus in natural waters. Mar. Chem., 10: 109-122.

Westcott, C.C. 1978. pH measurements. Academic Press, New York: $172 \mathrm{pp}$.

Wetzel, R.G. 1972. The role of carbon in hard-water marl lakes. In: G.E. Likens (Ed.). Nutrients and eutrophication. Amer. Soc. Limnol. Oceanogr. Spec. Symp., 1: 84-97. 